\title{
Integrating power-to-gas in the biogas value chain: analysis of stakeholder perception and risk governance requirements
}

\author{
Johanny Pestalozzi ${ }^{1 *}$ (D, Claudia Bieling ${ }^{1}$, Dirk Scheer ${ }^{2}$ and Cordula Kropp ${ }^{3}$
}

\begin{abstract}
Background: When integrating power-to-gas (PtG) in the biogas sector (BGS), it is essential to consider how risk is perceived and handled since it influences technology uptake, acceptance, and legitimacy. In this study, we aimed to identify factors that determine how risks are managed in the BGS grounded on stakeholders' perceptions of environmental and safety risks, and the socio-political, technological, and economic challenges associated with the adoption of PtG in this industry.

Methods: Semi-structured interviews were conducted with 27 experts located throughout Germany. They represented relevant institutions associated with the development of the BGS and PtG. Participants included expert stakeholders from science, industry, associations, and politics. The interview data were assessed by the use of thematic qualitative text analysis, followed by inductive reasoning, based on holistic and axial coding of the transcribed interviews.

Results: The participants predominantly trusted existing regulations to ascertain that environmental and safety risks from this energy concept are under control. The expert stakeholders were convinced that except for farm-based biogas facilities, there is adequate know-how in the BGS to appropriately manage risks of biogas and PtG technologies and thus prevent potential negative externalities. Furthermore, they were inclined to identify sociopolitical challenges, such as public criticism of biogas, and missing financial incentives as the most relevant matters to the development and adoption of PtG in this sector. The interviewees mainly identified politicians as responsible actors to handle identified risks and challenges. Such risk rationalities are characterized as hierarchist in the cultural theory of risk perception.

(Continued on next page)
\end{abstract}

\footnotetext{
* Correspondence: johanny.pestalozzi@gmail.com

${ }^{1}$ Institute of Social Sciences in Agriculture, Chair of Societal Transition and

Agriculture, University of Hohenheim, Schloss Museumsflügel, 70599

Stuttgart, Germany

Full list of author information is available at the end of the article
}

(c) The Author(s). 2019 Open Access This article is distributed under the terms of the Creative Commons Attribution 4.0 International License (http://creativecommons.org/licenses/by/4.0/), which permits unrestricted use, distribution, and reproduction in any medium, provided you give appropriate credit to the original author(s) and the source, provide a link to the Creative Commons license, and indicate if changes were made. 
(Continued from previous page)

Conclusions: Possible reasons behind the prevailing high level of risk tolerance among the participants of this study could be related to (1) strong reliance on governmental action, technical protocols, and the perception that others are responsible for risk management in the BGS; (2) a high confidence in expertise in the biogas industry to control risks; and (3) the tendency of experts to advocate biogas and PtG, linked to possible professional roles and motivational factors. These aspects may influence them to attenuate the urgency to prevent accidents and environmental risks, even if this can have undesirable consequences when incorporating PtG in the biogas industry. While critical environmental and safety risks are not acknowledged and adequately tackled, societal controversies may accentuate to the disadvantage of the BGS and the potential benefits linked to the integration of PtG in this field. We recommend implementing measures that enhance risk awareness within this community, urge interest groups to adopt collaborative risk management strategies and consider the involvement of multiple stakeholders in risk assessment and control, and likewise, address the particularities of the social context in defining strategies for risk management and communication.

Keywords: Biogas, Power-to-gas, Expert risk perception, Risk governance, Risk awareness, Risk amplification, Cultural theory, Stakeholder participation, Public opinion, Media

\section{Background}

\section{Renewable energy in Germany}

The transformation of the energy system for the sake of climate change mitigation and sustainability has become a critical political issue in many countries around the world [1-4]. The German energy transition approach-known as Energiewende-has set quantitative policy objectives towards low-carbon energy production, including goals for renewable energy shares, energy efficiency, and greenhouse gas (GHG) emission reduction targets. It is envisioned to reduce total GHG discharges by $70 \%$ in 2040 and at least $80-95 \%$ in 2050 compared to levels in 1990 [5, 6]. Within the power sector, renewable energy sources (RES) are anticipated to contribute $45 \%$ of the final energy consumption by 2040 and $60 \%$ by $2050[5,6]$. The German government implemented the Renewable Energy Sources Act (Erneuerbare-Energien-Gesetz, EEG) in 2000, stimulating the Energiewende primarily in the power sector. The EEG can be seen as the main political driver for the shares of RES that have been reached so far. The legislation has been amended several times and most recently in 2017 [7]. The electricity production from RES has substantially increased over two decades, raising its share of the primary energy consumption from $2.9 \%$ in 2000 to $13.1 \%$ in 2017 [8], contributing $36.2 \%(217,857 \mathrm{GWh})$ of the total electricity consumed in Germany in 2017 [9]. In the same year, renewable energies contributed $13.9 \%$ to heat consumption and $5.2 \%$ to the energy used in the transport sector [8]. A closer look among RES reveals that wind energy provided $17.7 \%$ of the total electricity demanded, while photovoltaic had a share of $6.6 \%$ [9]. As a biogenic renewable energy source, the biogas sector (BGS) supplied $5.4 \%$ of the gross electricity consumed in 2017 (32,500 GWh).

Similar to other RES, the production of biogas increased over the last decade. In 2017, a total of 9331 biogas facilities with an installed electrical capacity of $4550 \mathrm{MW}_{\mathrm{e}}$ were reported to be operating in Germany compared to 2050 plants $\left(390 \mathrm{MW}_{\mathrm{e}}\right.$ ) in 2004 [10]. Moreover, the BGS contributed to GHG reductions of 19.9 million tonnes of $\mathrm{CO}_{2 \text {-eq }}$ in 2017, provided 47,000 jobs, and generated a volume of 9.3 billion Euros in revenues [10].

\section{PtG as an energy storage concept in the German energy transition}

With the Energiewende in perspective, wind and solar power plants are the main pillars for transitioning the power sector in Germany in the coming years. However, these are fluctuating energy sources, causing seasons of electricity surplus as well as periods of electricity shortage [11]. With significant amounts of wind and solar energy facilities installed, renewable electricity production periodically exceeds consumption. What we observe for the time being is that wind turbines are provisionally disconnected in moments of excess power production in order to avoid a collapse in the electricity grid. Based on different modeling scenarios, it is expected that the surplus electricity amounts to 1.8-20 TWh in 2025 and 2040, respectively [12].

Against this background, flexible energy options gain importance to assist in balancing volatile renewable electricity and grid stabilization requirements. Energy storage concepts are being developed to store excess electricity, by conversion into thermal or mechanical energy (e.g., with pumped water and compressed air) or by chemically storing energy in the form of batteries, hydrogen, and methane [13].

In this regard, power-to-gas (PtG) is an energy storage concept that relies on a repository of electricity in the form of a chemical energy carrier with high energy 
density $[14,15]$. PtG also provides a potential for sector coupling by connecting the power, heat, and transportation energy sectors $[15,16]$. This concept consists of an electrolysis process as a central component, in which electricity is used to separate water into hydrogen and oxygen [14, 16]. The hydrogen produced can be used immediately as an energy source, or it can be transformed into other forms of energy such as methane, syngas, electricity, liquid fuels, or even chemicals [16]. In Germany, three main conversion routes of $\mathrm{PtG}$ are under development: first, the direct use of hydrogen as an energy carrier, i.e., fuel cells to run vehicles and chemical engineering facilities; second, hydrogen feed-in to the natural gas grid, although this is limited to permissible volumetric hydrogen maximum thresholds; and third, the methanation of hydrogen with carbon dioxide and an ensuing unrestrained storage of methane in the natural gas grid $[14,15]$.

\section{Integration of PtG into the biogas value chain}

This third approach-the methanation process with the technology of PtG-can be performed in two distinctive paths, either catalytical-chemical or through biological methanation (BM) [17]. For the conversion of hydrogen into methane, one needs carbon dioxide which can be provided by biogas, syngas, thermal facilities, air (via air capture), or from various industrial processes where this substance is generated as a waste gas [14, 15].

By implementing PtG in the biogas value chain via $\mathrm{BM}$, methanogenic archaea act as biocatalysts converting hydrogen and carbon dioxide into methane through hydrogenotrophic methanogenesis [17-19]. Various studies have shown the potential of BM to achieve methane content in biogas higher than 90\% [20-22]. Nevertheless, the overall PtG conversion efficiency from electricity to biomethane ranges between 49 and $64 \%$ at a pressure of 200 bar, which is typical of gas storage installations [23]. Once the biomethanation process is accomplished, the product can be stored in the natural gas grid, used as motor fuel, or employed for a cogeneration system to yield thermal and electrical energy $[14,17,19,24]$. As such, integrating PtG into the BGS provides flexibility and sector linkages, options that are strongly needed for the German Energiewende.

Concerning the political and economic context of biogas, under the latest amendment of the EEG in 2017, the business model of this industry shifted from the traditional feed-in-tariffs to an auction-based technology-neutral energy market, favoring cheaper and flexible renewable energy production and storage [25]. This tendering model represents a challenge for the conventional BGS to rapidly search for business models to remain competitive in a demand-driven renewable energy market.

PtG represents an opportunity for the BGS to provide renewable energy in a flexible form. However, high costs of PtG still represent a significant challenge in the development of this emerging technology. In this respect, Götz et al. [19] estimated a required investment of 35.8-38.8 million Euros in a scenario of a $36-\mathrm{MW}_{\text {el. }}$ PtG plant.

Although the economic feasibility of PtG remains a challenging aspect, the development and implementation of PtG projects can be seen all over Europe. In 2018, a total of 128 PtG research and demonstration facilities were reported to be operating in 16 countries across the continent, including Germany, Denmark, France, the UK, and Switzerland [16]. Those ventures were running for a variety of purposes, such as injection of hydrogen and methane into the natural gas grid and as a buffer for the generation of electricity for combined heat and power plants, as well as for the production of fuel and chemicals [16]. Besides leading the charts on total installed biogas plants in Europe, Germany has the largest number of PtG facilities in the region, accounting in 2018 to a total of 56 PtG projects distributed throughout the country [16]. The German Energy Agency (Deutsche Energie-Agentur) reports various PtG projects connected to biogas plants, e.g., "BioPower2Gas," "bioCONNECT," "Power-to-Gas-Pilotanlage Allendorf," "Power to Gas im Eucolino," and "Methanisierung am Eichhof" [26].

\section{Risks and challenges particular to the BGS influencing the integration of PtG}

While PtG represents a promising technological development for the German biogas industry, several environmental and safety risks, as well as socio-political and economic challenges remain [27]: first, environmental pollution (e.g., $\mathrm{CH}_{4}$ and $\mathrm{CO}_{2}$ leakages from anaerobic digestion from fermenters and storage tanks); second, health hazards to operators (e.g., potential suffocation and/or poisoning by being exposed to fermentation gases such as $\mathrm{H}_{2} \mathrm{~S}$ in areas processing input material, including radiation from generators in combined heat and power plants); and third, threats related to damages due to exposure to fire and explosions (e.g., from open flares, friction and grinding, hot surfaces, or from unplanned ignition of dust).

The German Federal Environment Agency (Umweltbundesamt) published a safety assessment in 2015, covering a sample of 300 biogas plants across the country [28]. The study revealed that up to $73 \%$ of the evaluated facilities presented critical safety risks. Some of the problems reported were associated with low risk awareness among operators, poor installations, unskilled personnel, lack of monitoring campaigns, and weak compliance with regulations [28].

In this regard, Casson Moreno et al. [29] compiled a global database in 2016, listing 169 cases of reported accidents in biogas value chains between 1995 and 2014 . An analysis of the geographical distribution of the cases shows that $96 \%$ of these accidents occurred within 
Europe and most of them in Germany. The instances described were predominantly associated with explosions, flares, biogas emissions from fermenters, and digestate spillages. Low risk awareness of plant managers and missing safety standards were identified as leading causes of accidents [29]. These findings are similar to those published in 2015 by the Umweltbundesamt.

The Biogas Trade Association (Fachverband Biogas), the major biogas business organization in Germany, published a study in 2015 comparing accidents from the agricultural sector as a whole, with those from biogas plants [30]. The report reveals a continuous and sharp increase in biogas-related accidents over time against a rather constant rate of incidences in the agricultural sector (from 14 events in 2003 per 100 biogas facilities to 269 in 2012, compared to 8.9 accidents per 100 agricultural firms in 2003 to 8.4 in 2012). A similar increasing trend of accidents in the German BGS has been reported by other authors [31, 32]. The documented incidents in biogas facilities occurred despite existing risk management and preventive initiatives such as safety and plant best management practice guidelines [28], the Technical Rules for Hazardous Substances (TRGS) [33], and the Explosion Protection Product Ordinance (11. ProdSV) [34].

Other concerning aspects of the German BGS relate to socio-political challenges linked to the public perception and discontent due to various controversial issues, especially in connection with the use of maize in this industry. Silage maize (Zea mays L.) represents the most predominant energy crop used for biogas production in Germany, cultivated in 1 million ha or $10 \%$ of the available agricultural area in the country [35]. Amidst the expansion of biogas production and growing maize areas, the term "Vermaisung" (maizification) has been coined as a stigmatizing term to criticize extensive maize cultivation associated with biogas as well as in disapproval of the political action in light of perceived wrong economic development and looming environmental risks [36, 37].

Evidence has been found regarding the negative ecological impact of biogas. Csikos et al. [38] found a direct correlation between an increment of biogas facilities and a consistent reduction in crop variety, arguing on land use homogenization in specific zones of Germany. Moreover, Laggner et al. [39] identified that areas with permanent pastureland systematically decreased in regions where silage maize cultivation augmented. Such land use transformation has been associated with significant detrimental environmental effects, including more considerable vulnerability to soil erosion from the wind as well as soil compaction due to the use of heavy machines $[40,41]$. This land-use change also causes larger organic matter mineralization and leaching of nitrogen [42-44], increased emissions of carbon dioxide and nitrogen from the degradation of organic matter [43], and adverse alterations in regional biodiversity $[45,46]$.
Moreover, conflicts of interest exist between maize cultivation for biogas and other agronomic markets. Competition for feedstock emerged between animal husbandry and biogas production since both rely on the same crop. The consequence has been that some producers reduced the ratio of maize for their dairy cows once investing in biogas, resulting in significant repercussions for the food processing industry [34]. There is also evidence that biogas led to an increase in agricultural land rental prices in Western German regions, with this being linked to competition for land due to higher profitability in biogas processing of initial producers compared to conventional farming $[47,48]$. These negative impacts received intense media coverage causing controversial discussions within civil society organizations and the public at large, which raised considerable distrust and caused a loss of legitimacy of the BGS in Germany [49].

\section{Aims}

There is potential for the BGS to play a key role in the German Energiewende. A crucial innovation option is to integrate PtG into the biogas value chain. Nevertheless, environmental and safety risks, as well as societal concerns associated with negative environmental impacts of the biogas expansion, are evident. Based on these premises, it is difficult to draw a picture on the future development of the BGS. In this context, our study objective was to map and explain stakeholders' perception of potential risks and challenges associated with integrating PtG in the biogas value chain, and of the governance options to control identified risks. To our knowledge, the present investigation is the first to address this topic, filling this literature gap, by prompting a discussion of the findings based on the theories of risk perception and risk governance [50-53].

\section{Methods \\ Approach to data collection}

Acknowledging that PtG is still an emerging technology, we based our assessment on the perception of experts in the German biogas sector. They were interviewed, aiming to (i) characterize what they identify as risks, challenges, and benefits of the BGS in combination with PtG; (ii) ascertain their normative claims towards risk perceptions, which influence their preferred risk management as well as whom they identify as responsible actors to handle risks and challenges; and lastly, (iii) provide policy recommendations for an improved risk governance in the biogas industry linked with PtG.

Semi-structured interviews are used as exploratory methods to gather descriptive data on a defined subject under investigation, without restricting the interviews to predefined questions or a schedule. This empirical approach 
allows the design of a catalog of questions (interview guide), outlining a set of inquiries on selected topics, leading the interviews to specific subjects, but not appointing a strict procedure or unique set of questions [54].

\section{Stakeholder selection}

We carried out interviews among expert stakeholders from science, industry, politics, and associations using a purposive sampling approach. This sampling technique focuses on identifying participants that fulfill a list of conditions stated by the researchers, in conformity with the aims of the study and the defined research questions [55]. Participants of the study should also be wellacquainted with the subject investigated and demonstrate a willingness to provide relevant and well-reflected opinions for the matter at hand [56].

The concept of stakeholder used in this study aligns with the description of Gerkensmeier and Ratter [57], relating to those who are representatives of any social group and organization relevant to a specific activity, are influenced by this activity, take part in the decisionmaking around it, are directly responsible for its management, or have impact or preeminence in the collective opinion.

Our interpretation of an expert follows the notion provided by Hitzler et al. [58], referring to an individual that has an "institutionalized authority to construct reality," together with the conventional notion of expert, a person qualified to discuss specific research questions in a domain of knowledge considered pertinent by the researcher [59]. In this regard, we refer to expert knowledge as that, which is "influential in structuring the conditions of action for other actors [....] in a relevant way," as proposed by Bogner and Menz in 2002 [60].

The criteria we followed for the identification of expert stakeholders were (i) a person who has been working within the biogas or PtG technology for multiple years in the industry; and/or (ii) someone who has published or is currently doing research in biogas, biomethane, or PtG; and/or (iii) a person who works for an association or a political organization dealing with conventional or novel topics pertaining to biogas and its derived products such as biomethane.

The interviewees were identified by primarily searching for recent publications in scientific journals, project databases, companies' homepages, and conference proceedings. In purposive sampling, to be eligible, potential participants need to suit the sampling criteria set by the researchers, to comply with the aims of the study $[54,55]$. Once suitability was proofed, the identified experts working in renowned research institutes, companies, associations, and political organizations related to the sector of biogas in Germany were then directly invited by phone and email.
Complementary to the purposive sampling technique, we used the snowball method, asking the initially selected participants for suggestions about potential collaborators. In the application of this method, the researcher verifies if the suggested individuals comply with the sampling criteria, and in this case, that they possess knowledge or experience as a basis for providing relevant insights to the study $[54,55]$. An advantage of this sampling method is the facilitation of access to influential stakeholders. However, there is also a risk of getting a skewed sample from a network with a particular standpoint towards the topic under research. In this study, three participants were obtained via snowball sampling, covering the sectors of science, industry, and politics, respectively. By following this mixed approach, we were able to integrate additional relevant actors of the German BGS that were not initially identified. The interviews were performed until data saturation was reached, i.e., when no additional information regarding the research questions was obtained from any new interview [55].

The final sample group included 5 females and 22 males with work experience ranging between 3 and 19 years in the field of biogas, PtG, or derived products (cf. Table 1). The 27 expert stakeholders that took part in this study represented four sectors as follows:

- Nine from science (i.e., working in universities, independent research institutes, or specialized think tanks);

- Seven from the industry (i.e., companies dedicated to the construction, operation, and maintenance of biogas plants; working with biogas installations combined with PtG; or firms trading biomethane);

- Six from associations (i.e., representatives of industrial and/or farm-based biogas-producing private organizations, as well as expert groups that provide consultancy on biogas systems but are not registered as associated with a research institution), and lastly;

- Five from politics (i.e., representatives of governmental institutions as well as a full-time politician).

The interviewed expert stakeholders work in institutions located all over Germany (cf. Fig. 1). We did not aim at coinciding with the current geographical distribution of biogas and PtG installations in Germany. Instead, our goal was to reach participants with relevant expertise on biogas and knowledge on PtG, who represented a diverse set of institutions associated to areas influencing or being influenced by the biogas industry, distributed all over the country.

It was not possible to include the opinion of farmers, NGOs, the media, and the general public in this study. Some of these stakeholders were mentioned by the 
Table 1 Characteristics of the participants and duration of the interviews

\begin{tabular}{|c|c|c|c|c|}
\hline \multirow[t]{2}{*}{ ID } & \multicolumn{3}{|l|}{ Stakeholder } & \multirow{2}{*}{$\begin{array}{l}\text { Interview } \\
\text { Duration (hh:mm:ss) }\end{array}$} \\
\hline & Sector & Gender & Experience (years) & \\
\hline 1 & Associations & Male & 8 & $00: 39: 58$ \\
\hline 2 & Associations & Female & 5 & $01: 46: 47$ \\
\hline 3 & Associations & Female & 15 & 01:04:39 \\
\hline 4 & Associations & Male & 8 & 01:29:29 \\
\hline 5 & Associations & Male & 15 & $01: 25: 25$ \\
\hline 6 & Associations & Female & 14 & $00: 51: 30$ \\
\hline 7 & Politics & Male & 10 & 01:15:33 \\
\hline 8 & Politics & Male & 9 & 01:11:09 \\
\hline 9 & Politics & Male & 3 & 00:41:07 \\
\hline 10 & Politics & Male & 6 & 01:02:38 \\
\hline 11 & Politics & Male & 17 & $00: 25: 01$ \\
\hline 12 & Science & Male & 19 & 00:58:07 \\
\hline 13 & Science & Male & 5 & 01:34:41 \\
\hline 14 & Science & Male & 15 & 01:34:49 \\
\hline 15 & Science & Male & 3 & $00: 44: 45$ \\
\hline 16 & Science & Male & 6 & $01: 30: 22$ \\
\hline 17 & Science & Male & 16 & 01:10:19 \\
\hline 18 & Science & Male & 16 & $01: 11: 26$ \\
\hline 19 & Science & Male & 8 & 01:17:32 \\
\hline 20 & Science & Male & 15 & $00: 52: 21$ \\
\hline 21 & Industry & Male & 8 & 01:05:43 \\
\hline 22 & Industry & Female & 10 & $00: 52: 11$ \\
\hline 23 & Industry & Male & 10 & $01: 26: 17$ \\
\hline 24 & Industry & Male & 4 & $00: 38: 57$ \\
\hline 25 & Industry & Male & 3 & $00: 53: 52$ \\
\hline 26 & Industry & Male & 9 & $00: 45: 14$ \\
\hline \multirow[t]{2}{*}{27} & Industry & Female & 18 & $00: 27: 56$ \\
\hline & Sectors: 4 & $\begin{array}{l}\text { Fem. (5) } \\
\text { Male (22) }\end{array}$ & Avg. $=10.19 \pm 4.96$ & Duration 01:04:22 (avg. \\
\hline
\end{tabular}

participants of this investigation, recognizing them as influencers in the public acceptance of biogas and PtG and the formation of risk attitudes in society. Although not directly asked, farmers were indirectly represented in this study through specialized associations, which are well-known for their close contact with farmers running biogas installations.

Interview procedure and content of the interview guide The interviews were performed face-to-face, in the working space of the expert stakeholders, with a duration of 50-90 min (cf. Table 1). The entire fieldwork was conducted over a period of 3 months and 23 days, with the date of the first interview being January 16, 2017, and the date of the last interview being May 8, 2017.
The conversations were performed in English and German, based on the language preferred by the participants. All of the interviews were tape-recorded and transcribed in a verbatim format with the assistance of the software MAXQDA.

An interview guide (cf. Additional file 1) was designed and provided to the participants in advance of the interview in order to familiarize them with the scope and aims of the investigation. This guide consisted of 15 open-ended questions structured into three sections. Section I focused on the experts' assessment of benefits, risks, and challenges associated with the adoption of PtG in the BGS, the identification of required management options, and responsible actors for handling risks and challenges. In section II, questions addressed potential transformations that could occur in the 


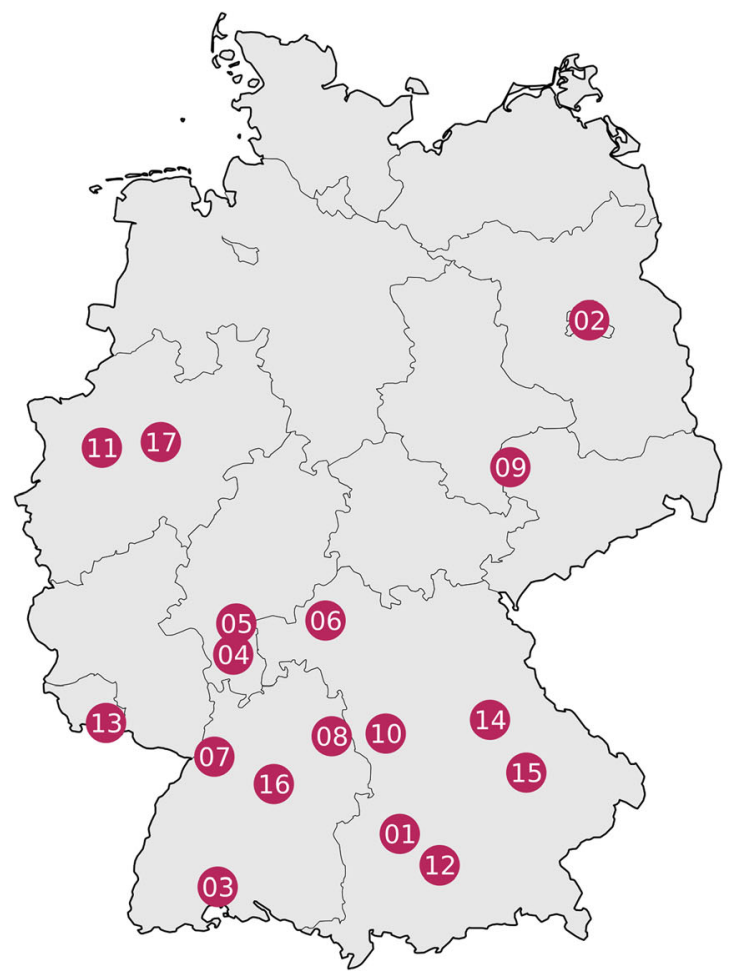

\begin{tabular}{llc}
\hline (D) & Location & Number \\
\hline 01 & Augsburg & 1 \\
02 & Berlin & 3 \\
03 & Bräunlingen & 1 \\
04 & Darmstadt & 1 \\
05 & Frankfurt & 1 \\
06 & Hammelburg & 1 \\
07 & Karlsruhe & 2 \\
08 & Kirchberg & 1 \\
09 & Leipzig & 2 \\
10 & Merkendorf & 1 \\
11 & Oberhausen & 1 \\
12 & Planegg & 1 \\
13 & Saarbrücken & 1 \\
14 & Schwandorf & 1 \\
15 & Straubing & 1 \\
16 & Stuttgart & 7 \\
17 & Unna & 1 \\
\hline & &
\end{tabular}

Fig. 1 Geographical distribution of the expert stakeholders interviewed in this study and number of interviews performed in each location

German biogas value chain deriving from the implementation of PtG, as well as the conditions necessary for establishing a biorefinery concept based on biomethane. In section III, experts were requested to express their opinion on political aspects that influence the BGS and its innovation through PtG. The participants were not asked to define risk, and a concept of risk was not provided to them in advance. We aimed at understanding their risk interpretation from the responses they gave.

We followed the risk definition of Aven and Renn [61] in the data analysis, referring to risk as "uncertainty about and severity of events and the consequences (or outcomes) of an activity with respect to something that humans value," with conventional interpretation of risk in social sciences alluding to environmental and safety issues [61, 62]. Concerning challenges, we relate to all matters that can be detrimental to the development of the BGS and the adoption of PtG in the biogas industry. Regarding technological risk perception, we adopted the understanding of Renn and Benighaus [63], denoting it as "the processing of physical signals and information about a potentially harmful impact of using technology and the formation of a judgment about seriousness, likelihood and acceptability of the respective technology."

\section{Qualitative text analysis}

We used the method of thematic qualitative text analysis (QTA) to process the data for our assessment
$[64,65]$. Following this technique, the transcripts of the interviews were systematically evaluated, structuring the content into categories and sub-categories, based on characteristics and patterns to answer the subject under investigation [54]. This process includes the assignation of codes or "labels" to sections of the data, e.g., a text that provides relevant content to answer the research questions.

The coding method comprised an iterative process of two phases [66]. In a first step, a holistic coding was performed throughout the entire dataset, in which provisional codes were assigned to relevant sections of the transcripts, examining the data in an exploratory manner [66]. A temporary category tree or "code system" was elaborated, grouping these codes into five categories and several sub-categories. In a second phase, a refinement of the codes and the code system was done, grouping related codes under the same theme and eliminating unnecessary ones. This latter method is called axial coding, as described by Saldaña [66]. The structure of the final code system can be found in Additional file 2, indicating the codes' hit counts (once per interviewee) for each of the four sectors represented in the investigation.

A narrative was elaborated from the processed data, following a case-oriented analysis as described by Kuckartz [64]. In this approach, the content present in codes and categories is succinctly described, systematically following the individual sectors represented in the study, with each 
of them forming a case. This technique facilitated the comparison of data between sectors and across various themes. However, it allowed only for qualitative conclusions, meaning that the number of expert stakeholders with specific opinions was not recorded in the process of analysis. Instead, the prevailing opinions in the sample group were given as a result.

Moreover, we followed inductive reasoning in the analysis of the data [64,67], systematically examining similarities and differences within each category and proceeded to derive generalizations once patterns were identified in the transcribed opinions of the participants. Although these generalizations are applicable for the studied sample group, they cannot be generalized to the entire biogas sector since that would require a broader scope on the represented groups of stakeholders. However, the findings obtained provide pertinent information on current risk perception among relevant stakeholders of the German biogas industry for the elaboration of the next generation of risk management strategies and decision-making concerning biogas and related innovations.

\section{Results \\ Disagreements and stand on benefits of implementing PtG in the biogas industry}

Although expert stakeholders disagreed as to which type of PtG plant best suits the country's energy requirements and how to efficiently handle associated concerns and uncertainties, there were economic expectations from this innovation among the participants. They, therefore, perceived the integration of PtG in the biogas value chain as a convenient approach for this industry, identifying various benefits (cf. Additional file 2, category I).

Interviewed stakeholders (except those from industry) considered that PtG fits current biological processes in the biogas production via BM. Moreover, they asserted that biomethanation is already well-known among biogas operators; therefore, they broadly assessed the integration of PtG in the biogas value chain as straightforward in operation.

The expert stakeholders emphasized that a significant advantage of implementing PtG in the BGS relates to the possibility of storing surplus renewable electricity from wind and solar power installations in the form of biomethane in the natural gas network. They indicated that in this form, the BGS assists in overcoming a critical bottleneck in the German Energiewende.

Moreover, PtG was identified by the interviewees as a concept that can help use exhaust carbon dioxide from biogas plants and hence use this gas in the synthesis of biomethane. The interviewees agreed and emphasized that this innovation connected with biogas plants helps to increase biomethane yields per unit of the substrate. Thus, they were convinced that PtG would also benefit the biogas industry to improve resource and material efficiency, potentially requiring less land for energy generation.

The participants also highlighted that by storing biomethane in the natural gas grid, this energy source can be geographically decoupled and serve multiple purposes in different sectors and markets. They described that methane produced from a biogas process could have several applications, ranging from the generation of electricity, heat, and transport fuel, to its utilization as a platform for substances to be used by the chemical industry. In this way, the production is beneficial to multiple sectors, while the electricity grid is stabilized.

Expert stakeholders from science, industry, and associations predominantly expressed positive opinions regarding this technological concept. In contrast, stakeholders from politics expressed moderate positive opinions regarding the benefits and potentials of incorporating PtG in the BGS.

\section{Environmental and safety risks}

Interviewed expert stakeholders indicated that the advantages deriving from the adoption of PtG in the BGS need to be analyzed under consideration of the risks and challenges associated with this energy concept. A list of risks and challenges was identified by the participants of this study under different themes (cf. Additional file 2, category II).

Most participants expressed that they envisaged no additional risks to emerge in the management of biogas facilities with PtG other than what currently exists. They generally believed that risks are under control. The expert stakeholders predominantly proposed that the likelihood and severity of accidents and environmental impacts across the biogas value chain linked with PtG can be minimized by relying on the existence and effectiveness of current safety regulations and the acquired experience in the BGS. Most of the expert stakeholders from politics, science, and associations agreed that biogas producers have worked with hydrogen and similar flammable gases before. In their view, biogas producers know how safely to handle these issues. These participants thus considered that PtG would not add more risks than those currently faced by biogas operators. Expert stakeholders from industry showed the lowest concern on environmental and safety risks, exhibiting strong confidence that potential risks can be kept under control. These participants particularly called for a reduction in safety and process regulations, arguing that they make the biogas activity bureaucratic and unnecessarily time-consuming.

Concerning risks of handling microorganisms in a biogas facility after adopting PtG and the potential pollution in case of accidents, expert stakeholders from science, politics, and associations remarked that producers already have experience with handling fermented materials. Thus, they believed that the potential risks of soil contamination from a biogas and PtG facility are minor. 
Nevertheless, some expert stakeholders from politics exhibited concern about the level of complexity that PtG could represent for some biogas operators and drew attention to the need for appropriate hygienization of the fermented by-products from the biogas production process connected with the PtG system. These expert stakeholders indicated that the hygienization of the digestate is still a controversial topic in German society and should, therefore, be taken into consideration.

Expert stakeholders from associations highlighted a particular type of risk, namely that some companies in their eagerness to sell equipment would be willing to propose PtG to biogas producers that do not have adequate infrastructure and skills for implementing this concept. Some expert stakeholders from politics also exhibited preoccupation in relation to a possible continuation of extensive maize cultivations, which could be aggravated once a PtG concept is adopted, if the reliance on energy crops remains.

A few expert stakeholders acknowledged accidents that previously occurred in the BGS. Among those were participants from science that showed some concern about risks linked with hydrogen and methane management in biogas plants connected with PtG, because of fugitive gas emissions and potential risk of explosions. Expert stakeholders from industry mostly neglected the occurrence of severe accidents in the BGS and deemed that various mishaps from biogas presented in the media had often resulted from political discourses and not always from the existence of evidence about the accidents. They asserted that politicians have their agendas, which they pass on to the population, sometimes regardless of the facts. In turn, participants from the political sector emphasized that people's criticism was substantiated.

If not neglecting accidents in biogas facilities, interviewees mostly said that farmers operating biogas plants are responsible for the misfortunes of the BGS. Moreover, several expert stakeholders accentuated that this industry is mainly driven by economic interests rather than environmental concerns. The interviewees indicated that farmers had built precarious biogas installations, lacked know-how on the technology, followed no safety measures, and typically did not apply sustainable agricultural practices. Besides these management matters, some expert stakeholders from politics, science, and industry considered PtG and biogas as complex topics among technological challenges. They indicated that some biogas operators (especially farmers) do not entirely grasp the technical details of the biological and physicochemical processes involved, which they perceived as a difficulty to safely manage biogas facilities linked with PtG.

In the continuation of this reasoning, the interviewees believed that PtG has the potential of transforming the value chain of the BGS, by shifting management from farmers to more industrial plants, where they identify the personnel is better trained. Moreover, PtG may change the cooperation style among these farm-scale and industrial plants. Some interviewees suggested that farmers would solely become suppliers of raw material to industrial plants instead of also being operators of biogas facilities associated with PtG.

Although this belief was widespread among the interviewees, a few expert stakeholders from industry, politics, and associations believed that farmers could also operate PtG, provided the technology is kept simple and is scaled to a level that small biogas producers can run it. We also observed uncertainty among some of the expert stakeholders from science, politics, and associations, who expressed that adopting PtG in the biogas value chains will not directly mean an improvement in the sustainability of the BGS. They explained that sustainability measures need to be taken throughout the production chain of biogas, especially in the cultivation of energy plants.

\section{Societal challenges}

Several expert stakeholders from industry, science, and associations argued that people have a negative stand against the BGS because they do not have enough and adequate information about the technology and the overall sector (cf. Additional file 2, category II. sub-category b). Moreover, these participants deplored that the general public is not willing to read specialized and extended publications to understand the biogas process and form an educated opinion about the technology and the industry.

Expert stakeholders from these sectors agreed that the current situation represents a barrier to increase the acceptance of biogas in German society. Thus, they were afraid that it could negatively influence the adoption of innovations like PtG as part of the biogas industry. Another aspect stated by these expert stakeholders, including participants from politics, was that people in Germany are not keen to pay for biogas as a renewable energy provider. They do not expect people to be willing to support the provision of public economic incentives for biogas as an energy storage technology in combination with PtG. They rather expect that, as long as people do not relate to the rationale and environmental services that underpin the biogas concept, they will continue to criticize the BGS and will mainly focus on the availability of cheap energy. They condemned that attitude and indicated it is a fundamental problem in today's German society.

Interviewees from science, industry, and associations emphasized the need to properly inform and sensitize the general public on the benefits of biogas separately and in combination with PtG. Participants, especially from industry and science, had confidence that once 
people are informed about the benefits of these systems, they will accept them as green and renewable energy options.

\section{Responsible actors and suggested measures for managing risks and challenges}

Despite the accidents allegedly caused by farmers in the BGS, biogas producers were not often perceived by the interviewees as responsible for handling risks and challenges in the BGS or the possibly incorporated PtG (cf. Additional file 2, category III). Moreover, the interviewees mentioned in less frequency "training" or "safe plant management" as necessary in comparison with other measures (cf. Additional file 2, category IV).

The expert stakeholders predominantly identified politicians as primarily responsible actors, to take care of risks and challenges of the biogas industry, followed by research institutions, the media, and lastly, producers' associations. All the interviewees emphasized the need for policy measures to efficiently handle risk and concerns related to the development of biogas production and technical uncertainties linked with PtG, as well as the promotion of this renewable energy concept among the general public.

Unlike the common perception within the participants of this study, interviewees from politics perceived the government to have fewer obligations in managing risks and challenges compared to other participating expert stakeholders. Interviewees from politics mentioned scientists as primarily responsible, indicating that their task is to provide politicians with solutions to avoid or minimize risks and challenges linked to the implementation of PtG in the biogas sector.

Besides possible political agendas to sway the public, the media were identified as essential influencers of people's opinions. Various expert stakeholders from associations, science, and industry believed that in the past, negative news about the BGS had been selected and featured by the media. Some participants had the impression that false information about the impacts of the BGS had been disseminated. Similarly, various interviewees expressed that serious topics were overly simplified, for example, with individual accidents being generalized as if they were happening in the entire BGS. The expert stakeholders predominantly believed that a negative sentiment against biogas remains in people's minds, potentially influencing the acceptance of technologies associated with the biogas industry.

Despite considering politicians as main actors responsible for handling the risks and challenges of the BGS and in combination with PtG, several expert stakeholders from associations, science, and industry distrusted politics and politicians. They perceived this group as being strongly influenced by lobbyists, aiming to change the energy policy (EEG) in favor of specific industries, at the expense of the BGS. In addition, expert stakeholders from industry and associations believed that the constant modifications of the EEG demonstrate that policymakers have not yet developed a coherent long-term vision for the deployment of RES in the country.

Except for participants from associations, the interviewees identified their sectors to be less responsible for tackling the mentioned risks and challenges linked with biogas and PtG compared to expert stakeholders from other areas (cf. Additional file 2, category III). Participants from associations interpreted responsibility as an urgency to strengthen their presence in the public discourse. They highlighted that the influence of the BGS as a lobby group in decision-making is minimal in comparison with other sectors, such as speakers from the coal industry, farmers' association, and other renewable energy industries. They saw this lack of influence as one of the reasons for the declining political support to the biogas industry.

Similarly, several interviewees, predominantly from science, accentuated the need for "image campaigns" to increase acceptance and knowledge about biogas and PtG, which can provide the public with information on these technologies in a simplified way (cf. Additional file 2, category IV). They understood that this approach would enable people to differentiate between PtG versus traditional biogas production. In this way, they expect to avoid potential criticism of biogas and PtG from society.

Regarding research and development, mostly scientists suggested continuing providing incentives for further investigation. Additional file 2, category $\mathrm{V}$, offers a list of topics discussed by the stakeholders requiring further research. Expert stakeholders from industry, associations, and politics highlighted the need to assist the establishment of more pilot plants, stimulate communication among expert stakeholders in order to find strategies to increase societal acceptance, demonstrate convincing business plans to biogas producers, and provide training for safe plant management and construction.

\section{Discussion}

\section{Cultural determinants in the perception of risks}

Technological risk perception can be described as a specific judgment of potential damage to materials, environmental, social, or financial systems associated with a technology and the assessment of its probability, relevance, tolerability, and subsequent acceptance or refusal $[63,68]$.

We identified a high risk tolerance among the expert stakeholders in general regarding environmental and safety risks from biogas plants associated with PtG. They think that potential risks are under control and rely in particular on the experiences gained to date in the BGS and the existing safety regulations. The perception of 
low risk was unexpected given the findings of the Federal Environment Agency about serious safety deficiencies in biogas plants [32] and the multiple cases of accidents reported in this sector [69-72].

We interpreted the findings in the light of the cultural theory of risk (CT) [40-45] which understands risk perception as a socially predetermined selection by which "individuals choose what to fear (and how much to fear it), in order to support their "way of life"' [73]. With a focus on collective, social, and group-specific conventions that influence individual risk perception, CT sheds light on the filters that influence the opinions of laypersons and experts on the risks, acceptance, and legitimacy of biogas and the implementation of PtG. Douglas and Wildavsky $[73,74]$ highlighted the social variability of risk perceptions and assessments from the early 1980s. By focusing on the inherently political character of risk controversies, they offered an approach to the interpretation of risk issues that contrasts sharply with economic, engineering, and psychometric understandings.

In view of a large number of risk potentials in modern societies and the difficulties in reliably estimating them, they assume that conceptions of risks are determined by commitments towards different forms of social organization and solidarity. These forms differ in the scope to which the individual is integrated into a social circle (group) and in the extent and density of social regulation and control (grid). The cross-tabulation of group and grid results in four basic types of social relationships (ways of life): "individualistic," "hierarchical," "egalitarian," and "fatalistic" [75-77]. These types can be assigned specific underlying assumptions about the stability and endangerment of natural systems (nature as benign, perverse/tolerant, ephemeral, or capricious) as well as different patterns of risk attribution. Social actors operating in small groups with high social integration and low hierarchical structure (high group, low grid) tend to have strongly "egalitarian" and risk-averse (fundamentalist) attitude to technology and environmental risks, while actors in rational organizations with strong rules (low group, high grid) tend to rely hierarchically on strong regulations for risk control. Thus, "hierarchists" advocate a clear division of roles in risk management and exhibit high confidence in regulations and the influence of experts and institutions to control risks $[73,74,78-80]$. Individualists, on the other hand, prioritize individual freedom and responsibility (low group) and favor market-based solutions and self-policing over top-down regulations (low grid).

The CT has been examined in studies discussing risk perception both among laypeople and experts [75-77] also in relation to risk assessment of bioenergy projects [81]. It has been associated with the polyrationality theory and the concept of rational choice, interpreting stakeholders' argumentations as perfectly logical and rational under consideration of people's interests and the legitimacy of their opinions and concerns [81-83].

The predominant risk perception among the interviewees of this investigation corresponds to the hierarchical rationality of the CT. Yet they appear to consider risks as an issue that threatens the permanence or development of the BGS and leads to a lack of federal incentives and stigmatization of the biogas industry, which we named in this study "socio-political challenges" (cf. Additional file 2, category II, sub-categories b and c).

\section{Why stakeholders focus on socio-political aspects}

Reasons that can explain the emphasis of the interviewees on socio-political issues and not on environmental and safety risks are, firstly, that stakeholders feel uncertain about the financial future of the sector due to recent changes in the incentive mechanism by the EEG. This uncertainty is justified by evidence from Denmark, where the development of the BGS stagnated (1990s-2009) due to a decrease in political support [84]. Secondly, respondents may consider the benefits to be larger than the risks associated with the technology, an aspect generally discussed in the risk perception literature [85].

Thirdly, the participants in this study have a high familiarity with the technologies and their risks due to their many years of work with biogas, PtG, and its by-products (cf. Table 1), which may contribute to an attenuation of risk perceptions [86]. Other authors have discussed this issue, in which experts' risk perception is influenced by the level of acquaintance they develop with a technology, lessening the perceived significance of risks [87]. In this regard, Sjöberg [88] found evidence that experts are particularly inclined to identify low risks in areas related to their field of knowledge. They may show overconfidence in their assessments, and their available data may not increase precision in their estimations $[89,90]$. As a consequence, experts can develop increased self-confidence when they believe that risks are under control [91], and they may ignore serious risks of accidents and possible negative environmental impacts [29, 69, 70, 72].

Besides uncertainty and familiarity, professional affiliations and personal interests may have also influenced the judgments of the interviewees in this study. Literature in risk perception shows that expert risk judgments can be affected by the professional roles and ideologies of the participants and can be subject to motivational and cognitive bias [86, 87, 92-94]. This means that the expert stakeholders may disregard relevant risks associated with both techniques that could challenge the rationale for further development of these technologies.

Sjöberg [86] suggested a classification of roles in expert risk assessment. This author proposed that experts can be characterized as (a) promoters, embracing risks in exchange of benefits; and (b) protectors, warning against evident or 
latent risks. Based on this categorization, the expert stakeholders from science, associations, and industry in this study appear as promoters of PtG and biogas, also in terms of high risk tolerance, compared to expert stakeholder from politics who showed a predominant role of protectors, emphasizing topics of interest and concerns of a diversity of social groups.

The overall high risk tolerance showed by the expert stakeholders also indicates a kind of risk denial, as described by Fromm [95]. This is an attitude linked with what Weinstein [91] calls optimism bias or unrealistic optimism. This concept indicates that people tend to perceive risks under their domain to be less relevant than those affecting other people's fields. Stakeholders strengthen this risk attitude by believing that they possess specific characteristics or possibilities that lessen the probability or severity of risks [96].

Another aspect is the argument provided by Van der Pligt [97], who explained that people could be inclined to assume risk denial, seeking to lessen distress and worry associated with risks. This could be the case of stakeholders of the BGS amidst changing conditions of public financial incentives for biogas.

However, it can also mean that they have developed, in the meantime, individualistic risk rationality based on a sector-specific belief in the robustness of nature to withstand changes, based on their interests in PtG use and the expected advantages. The perceived benefits of $\mathrm{PtG}$ in connection with biogas were expressed in technical aspects, such as energy storage opportunities in the form of grid stability. The interviewees also emphasized the use of exhaust $\mathrm{CO}_{2}$ from biogas processing for reinjection in digesters to increase $\mathrm{CH}_{4}$ yields as well as the flexibility of using this gas in different energy sectors. These aspects are in agreement with results on comparisons of various PtG technologies by Götz et al. [19], analyses of carbon balances through $\mathrm{CO}_{2}$ methanation by Meylan et al. [24], and an assessment on the potential contribution of biogas in smart energy grids by Persson et al. [98].

The interview statements would also have a more strategic character, expressing the participants' perception that the lack of public acceptance and state support is unjustified given the existing environmental and safety regulations. Respondents expressed strong concerns about the economic feasibility of PtG and biogas, including the lack of political support through financial incentives. This perception is aligned with their predominant hierarchical rationality. They blame inappropriate media coverage for the situation and stress that the risks are less technical than socio-political.

Despite the generalized high risk tolerance among the participants concerning potential undesired impacts from adopting PtG in the BGS, some of them acknowledged past accidents in biogas facilities, which may persist after adopting PtG. However, interviewees largely blamed farmers as responsible for mishaps in the BGS.

\section{Justification of distrust in farmers}

The expert stakeholders argued that farmers are solely responsible for accidents in the BGS, lacking expertise and building unsafe biogas plants. Based on this argument, most of the interviewees were inclined to suggest the installation and operation of PtG plants by specialized groups and hightech facilities. Despite the accusation directed towards farmers, we found reports of accidents in the BGS both from biogas plants operated by farmers and from industrial facilities. Examples of recent accidents related to farmer-operated plants occurred in Weißenburg (Bavaria) in 2017 [99], in Kißlegg (Baden-Württemberg) in 2016 [71], in Rockenbach (Bavaria) in 2018 [100], and Treischfeld (Hesse) in 2015 [101]. Incidents from biogas plants operated by companies were recently reported in Engstingen (Baden-Württemberg) in 2017 [102], in Segeberg (Schleswig-Holstein) in 2018 [103], in Wuthenow (Brandenburg) in 2017 [104], and Thierbach (Saxony) in 2016 [105].

In light of these cases, one may assume that there is a common parameter causing accidents in both biogas plants run by farmers and among those operated by high-skilled workers in large-scale industrial plants. This aspect is confirmed by a study of accidents in biogas installations, which concludes that the reasons are fundamentally related to low risk perception and overconfidence among plant operators [29]. They tend to perceive hazards in biogas processing as less risk-prone than the handling of conventional chemical processes.

Although accidents are reported to occur in biogas installations run by both types of operators, one cannot ignore evidence indicating that there are farmers handling biogas plants that have limited training in safety measures and procedures for a reliable plant operation [33].

\section{Similarities in risk construction of experts and laypeople}

Renn and Rohrmann [106] elaborated a comprehensive framework named "Four context levels of risk perception," in which all known aspects that influence people's risk perception are compiled. These factors are (i) heuristics (e.g., individual and collective wisdom); (ii) cognitive-affective (e.g., stigmata, reference knowledge, personal beliefs, and emotions); (iii) socio-political institutions (e.g., social values and trust, media influence, personal values, and interests); and (iv) cultural context (e.g., worldviews, personal character, purpose, and cultural institutions) $[63,106]$.

The findings of this study provide evidence that experts' risk assessments could be influenced by the same factors determining laypeople's risk perception, increasing or lowering their tolerability towards risks, e.g., when being influenced by cognitive heuristics, a kind of rule of 
thumbs or mental shortcuts, easing the assessment of complex risks [107].

Other researchers have also described that experts take a stand when managing technological risks and construct attitudes towards them not only based on their expertise but also subject to various factors such as values, beliefs, sociodemographics, and cultural aspects [76, 86, 87, 108, 109].

\section{Knowledge to increase technology acceptance}

Expert stakeholders from science and industry showed confidence in the public's acceptance of biogas and PtG once adequate information has been communicated. The reliance on knowledge as a central factor for technology acceptance has also been found in other studies assessing technological risk perception among experts $[76,110-112]$. In contrast, respondents from politics emphasized various controversial BGS' issues, which had previously been criticized in German society, such as pollution and accidents. These participants worried that if fears are ignored, the criticism could intensify. These findings exemplify the critical challenges in managing technological risks. On the one hand, knowledge on innovations should be available to the public, but on the other hand, people's risk perceptions need to be acknowledged and addressed to gain legitimacy and facilitate acceptance since one is not a substitute for the other.

\section{Increasing risk awareness and stakeholder engagement through risk governance}

Based on their predominant hierarchist rationality, the interviewees assert that there is no need for further risk management strategies in the BGS, considering the implementation of PtG. However, resilient risk management goes beyond being conscious of the existence of laws. Besides compliance with regulations, it is necessary to handle risks in a comprehensive, preventive, and participatory way, which is aligned with the norms, values, and interests of the social context of a technology [53]. These elements are comprised of the notion of risk governance, which is a relevant concept for laying out strategies to increase awareness and managing risks in the BGS.

Renn and Klinke [53] define risk governance as the compound organizational and directive structure to lead and regulate the shared interest and actions of social groups to mitigate and avert risk problems. This concept contributes to the risk governance framework being developed for the International Risk Governance Council (IRGC). It consists of a series of recommendations for decision-makers to facilitate seizing benefits and extenuating associated risks via a comprehensive, multisectoral, and participatory approach [50].

The proposed risk governance mechanism comprises the following stages: (i) preliminary assessment, describing risk characteristics based on inputs from relevant stakeholders and framing the risk issue and the approach to its governing for the following steps; (ii) multisectoral risk appraisal, integrating professionals from diverse disciplines to understand the scope of risks and potential consequences; (iii) risk characterization and evaluation and classification according to their tolerability or acceptability after considering both expert recommendations and people's concerns; and (iv) risk management, which takes place once data from previous steps have been studied and decisions are made regarding control options, performance monitoring, and feedback [51-53].

Throughout these steps, risk information and stakeholder engagement are continuously and cross-sectorally integrated. This aspect is of particular importance for achieving legitimacy in the event of diverging argumentations to characterize risks, their seriousness, and potential relevance of potential impacts [53], and in the early stages of development of an innovation, in which the course of action and effects of technology can be debated and steered [113, 114].

The IRGC categorizes the specific advantages of engaging stakeholders in the process of risk governance to promote (i) transparency on the mode of operation of an organization; (ii) fairness and diversity, by integrating different groups in the process of risk management and providing opportunities to express people's opinions; (iii) efficiency and pragmatism, gathering useful input that can help handle risk issues in their societal context; and (iv) improvement in risk governance, by creating an inclusive, organized, and reflective mechanism, communicating outcomes in the process and optimizing competence for risk management [115].

In this respect, the BWPLUS project conducted in the region of Baden-Württemberg (Germany) sought to identify aspects that help increase local PtG acceptability. Interviewed experts of that study suggested that a risk perception assessment should be performed among all regionally affected communities, considering the involvement of diverse stakeholders in the project development. This approach may help increase communication and collaboration among various interest groups and develop transparency in the process of risk assessment and management [116]. Expert stakeholders of the BWPLUS project also recommend strengthening dialog with the general public as a measure to promote the reception of the PtG technology [86, 87].

Besides stakeholder integration, the efficiency of a risk governance framework is also subject to the dexterity of organizations managing risks-i.e., those in charge of risk control in a specific context-to adequately administer support resources such as (i) institutional and financial agency (e.g., structures and instruments for problem-solving and to operationalize intentions, leadership appointment, and 
legitimation and readiness of a system for prompt execution), (ii) technological assets (e.g., compilation of data, digital devices, and information programs), and (iii) available skills and social capital (e.g., abilities, know-how, and scientific networks) [50, 52, 53].

\section{Increasing communication about roles and responsibilities between stakeholder groups}

The interviewees perceive their respective sectors to be less responsible than others for handling risks and challenges of biogas and in connection with the technology of PtG. They firmly rely on public policies as crucial means to manage risks and challenges in the biogas industry.

This finding suggests that stakeholders of the BGS may benefit from having more collaboration and discussion about required roles and actions in handling risks and challenges in biogas and its innovations. This aspect is essential for robust, effective, and legitimate risk governance [50, 117]. The stakeholder theory of Freeman $[118,119]$ validates the importance of defining functions among different interest groups to achieve successful management of projects.

Despite the solid confidence in politicians to manage risks and challenges in the BGS, various expert stakeholders from science and industry, but fewer from associations and political organizations, show distrust in decision-makers, whom they perceive to be influenced by lobby groups when deciding on revisions to the EEG.

The arguments of the interviewees indicate that although there is an expectation that politicians provide public incentives to promote the biogas industry, there are expert stakeholders who do not perceive politicians as independent actors who will defend the broader public interests. Notions on risk governance emphasize the relevance of trust in social institutions and authorities since this is a prerequisite for a legitimate, robust, and effective mechanism to handle risks [50,63].

\section{Risk amplification by media}

The expert stakeholders explain that selected news about the biogas industry was broadcasted to influence the public opinion, featuring and generalizing accidents as if they occurred in the entire BGS. This finding is in line with the social amplification of risk framework (SARF), a notion developed by Kasperson and associates in the late 80 s $[80,120]$.

These authors explain that beyond the direct physical detrimental effects of misfortune, other serious ripple effects occur in society, including the ruin of whole industries due to risk amplification. In this process, the media plays a crucial role in processing and transmitting information on risks, accentuating, or attenuating its characteristics. This process occurs by presenting selected facts, providing specific interpretation, and associating social values and judgments to appeal for a particular course of action [80, 120].

In this respect, Kasperson et al. [121] associate the concept of technology stigmatization with the SARF, describing the mechanism in which technology is marked with undesirable characteristics and seen as damaging or inferior. Stigmatized techniques are as a result repudiated by people, potentially causing multiple ripple effects, such as societal distress and increased distrust in risk management agents and institutions, economic and job losses, and may lead to the disappearance of a sector [120-122]. This stigmatizing process requires full attention among stakeholders of the BGS, especially decision-makers, to appropriately handle factors and mechanisms that induce people's risk perception of technologies.

\section{Conclusions}

This article refers to the cultural theory of risk to explain different risk understandings, following its grid-group typology, and draws recommendations based on the risk governance framework. The high risk tolerance found among the interviewed expert stakeholders of this study can be related to (1) their predominantly hierachist perception of risks, (2) high confidence on expertise in the biogas industry to control risks, and (3) professional roles and motivational factors. These attitudes may be determinants of the preferred risk management approaches in the sector. The far-reaching tendency to estimate risks as low and disregard their possible intensification in the further adoption of PtG into the BGS can lead to more accidents and thus to the deepening of social controversies. We recommend implementing measures that enhance risk awareness within this expert stakeholders' community, urge them to implement collaborative risk management strategies, consider the involvement of multiple stakeholders in risk assessment and control, and regard the peculiarities of this sector's social context in their approaches for risk management and communication. For further research, we suggest performing a similar investigation among opponents of biogas and PtG and integrate stakeholders from sectors that were not represented in this study. In this way, additional evidence can be obtained on the kind of determinants that influence risk perception among participants defending other interests. Lastly, we propose to extensively study the application of the SARF and the technology stigmatization theory in the biogas industry, on the adoption of PtG. This notion can provide detailed insights on the media's influence on risk perception and communication in the BGS and its innovations. 


\section{Supplementary information}

Supplementary information accompanies this paper at https://doi.org/10. 1186/s13705-019-0220-5.

Additional file 1. Interview guide.

Additional file 2. Code system and hit counts (once per interviewee) obtained from the qualitative data analysis.

\section{Abbreviations}

BGS: Biogas sector; CT: Cultural theory; EEG: Renewable Energy Sources Act; GHG: Greenhouse gas; IRGC: International Risk Governance Council; PtG: Power-to-gas; QTA: Qualitative text analysis; RES: Renewable energy sources; SARF: Social amplification of risk framework

\section{Acknowledgements}

We thank the Ministry of Science, Research and the Arts of the State of Baden-Württemberg (MWK) for providing us with a research grant to conduct this study. We are also grateful to all interviewees who kindly participated in this investigation, and likewise, thank the editor, Assoc. Prof. Dr. Inge Stupak, as well as reviewers of this journal, who provided us with critical and thorough feedback to improve the quality of this article.

\section{Authors' contributions}

JP was the main responsible for the design, data collection, analysis, and interpretation of the results of this study. CK complemented the discussion related to the cultural theory and together with CB and DS provided relevant feedback for the improvement of the article's clarity. All authors read and approved the final manuscript.

\section{Funding}

This investigation was financially supported by the Ministry of Science, Research and the Arts of the State of Baden-Württemberg (MWK) under the grant number 7533-10-5-102. Moreover, this project was part of the consortium Bioeconomy Research Program Baden-Württemberg and was associated with the Graduate Program: Bioeconomy Baden-Württemberg Exploring Innovative Value Chains (BBW ForWerts). Neither the MWK nor the BBW ForWerts influenced the design, implementation, or the documentation of this research.

\section{Availability of data and materials}

The datasets generated and analyzed during the current study are not publicly available due to confidentiality reasons. However, the transcripts of the anonymous interviews are available on reasonable request.

\section{Ethics approval and consent to participate}

Not applicable.

\section{Consent for publication}

All participants consented the confidential publication of their contributions in this study.

\section{Competing interests}

The authors declare that they have no competing interests.

\section{Author details}

'Institute of Social Sciences in Agriculture, Chair of Societal Transition and Agriculture, University of Hohenheim, Schloss Museumsflügel, 70599 Stuttgart, Germany. ${ }^{2}$ Institute of Technology Assessment and Systems Analysis, Karlsruhe Institute of Technology, P.O. Box 3640, 76021 Karlsruhe, Germany. ${ }^{3}$ Institute of Social Sciences, Department of Sociology with Focus on Risk and Technology Research, University of Stuttgart, Seidenstraße 36, 70174 Stuttgart, Germany.

Received: 27 July 2018 Accepted: 6 September 2019 Published online: 18 September 2019

\section{References}

1. Zappa W, Junginger M, van den Broek M (2019) Is a 100\% renewable European power system feasible by 2050? Appl Energy 233-234:1027-1050. https://doi.org/10.1016/j.apenergy.2018.08.109
2. Zhang D, Mu S, Chan CC et al (2018) Optimization of renewable energy penetration in regional energy system. Energy Procedia 152:922-927. https://doi.org/10.1016/j.egypro.2018.09.094

3. Pischke EC, Solomon B, Wellstead A et al (2019) From Kyoto to Paris: measuring renewable energy policy regimes in Argentina, Brazil, Canada, Mexico and the United States. Energy Res Soc Sci 50:82-91. https://doi.org/ 10.1016/j.erss.2018.11.010

4. Washburn C, Pablo-Romero M (2019) Measures to promote renewable energies for electricity generation in Latin American countries. Energy Policy 128:212-222. https://doi.org/10.1016/j.enpol.2018.12.059

5. Fischer W, Hake J-F, Kuckshinrichs W et al (2016) German energy policy and the way to sustainability: five controversial issues in the debate on the "Energiewende". Energy 115:1580-1591. https://doi.org/10.1016/j.energy.2016.05.069

6. Bundesministerium für Wirtschaft und Technologie (2010) Energiekonzept für eine umweltschonende, zuverlässige und bezahlbare Energieversorgung. https://www.bmwi.de/Redaktion/DE/Downloads/E/energiekonzept-2010. html. Accessed 9 Jan 2019

7. Bundesministerium für Wirtschaft und Technologie (2019) Das ErneuerbareEnergien-Gesetz. https://www.erneuerbare-energien.de/EE/Redaktion/DE/ Dossier/eeg.html?cms_docld=132292. Accessed 27 Jan 2019

8. Bundesministerium für Wirtschaft und Technologie (2018) Development of renewable energy sources in Germany 2017: charts and figures based on statistical data from the working group on Renewable Energy-Statistic (AGEE-Stat), as at December 2018. https://www.erneuerbare-energien.de/EE/ Redaktion/DE/Downloads/development-of-renewable-energy-sources-ingermany-2017.pdf?_blob=publicationFile\&v=17. Accessed 10 Jan 2019

9. Umweltbundesamt (2018) Erneuerbare Energien in Deutschland Daten zur Entwicklung im Jahr 2017: Hintergrund, März 2018. https://www.bioenergie. de/download_file/view/904/708. Accessed 20 June 18

10. Fachverband Biogas e.V. (2018) Branchenzahlen 2017 und Prognose der Branchenentwicklung 2018, Stand: Mai 2018. https://www.biogas.org/ edcom/webfvb.nsf/id/DE Branchenzahlen/\$file/18-05-25_Biogas Branchenzahlen-2017_Prognose-2018_end.pdf. Accessed 10 Jan 2019

11. Lauer M, Thrän D (2017) Biogas plants and surplus generation: cost driver or reducer in the future German electricity system? Energy Policy 109:324-336. https://doi.org/10.1016/j.enpol.2017.07.016

12. Statista (2018) Volumen der zu speichernden Stromüberschüsse in Deutschland in den Jahren 2025 und 2040 (in Terawattstunden). https://de. statista.com/statistik/daten/studie/222199/umfrage/volumen-der-zuspeichernden-stromueberschuesse-in-deutschland/. Accessed 21 June 2018

13. Garmsiri S, Rosen M, Smith G (2014) Integration of wind energy, hydrogen and natural gas pipeline systems to meet community and transportation energy needs: a parametric study. Sustainability 6(5):2506-2526. https://doi. org/10.3390/su6052506

14. Leonzio G (2017) Design and feasibility analysis of a Power-to-Gas plant in Germany. J Clean Prod 162:609-623. https://doi.org/10.1016/j.jclepro.2017.05.168

15. Schiebahn S, Grube T, Robinius M et al (2015) Power to gas: technological overview, systems analysis and economic assessment for a case study in Germany. Int J Hydrog Energy 40(12):4285-4294. https://doi.org/10.1016/j. ijhydene.2015.01.123

16. Wulf C, Linßen J, Zapp P (2018) Review of power-to-gas projects in Europe. Energy Procedia 155:367-378. https://doi.org/10.1016/j.egypro.2018.11.041

17. Lecker B, Illi L, Lemmer A et al (2017) Biological hydrogen methanation - a review. Bioresour Technol 245(Pt A):1220-1228. https://doi.org/10.1016/j. biortech.2017.08.176

18. Bailera M, Lisbona P, Romeo LM et al (2017) Power to Gas projects review: lab, pilot and demo plants for storing renewable energy and CO2. Renew Sust Energ Rev 69:292-312. https://doi.org/10.1016/j.rser.2016.11.130

19. Aicher T, Iglesias M, Schaub G, Götz M (2014) Arbeitspaket 5: Betrachtungendes Gesamtsystems im Hinblick auf Dynamik und Prozessintegration, energiewasser-praxis 65:51-55. http://www.dvgw-innovation.de/fileadmin/dvgw/ angebote/forschung/innovation/pdf/1411 aicher.pdf.

20. Luo G, Angelidaki I (2012) Integrated biogas upgrading and hydrogen utilization in an anaerobic reactor containing enriched hydrogenotrophic methanogenic culture. Biotechnol Bioeng 109(11):2729-2736. https://doi. org/10.1002/bit.24557

21. Burkhardt M, Busch G (2013) Methanation of hydrogen and carbon dioxide. Appl Energy 111:74-79. https://doi.org/10.1016/j.apenergy.2013.04.080

22. Rachbauer L, Voitl G, Bochmann G et al (2016) Biological biogas upgrading capacity of a hydrogenotrophic community in a trickle-bed reactor. Appl Energy 180:483-490. https://doi.org/10.1016/j.apenergy.2016.07.109 
23. Bernacchi S, Weissgram M, Wukovits W et al (2014) Process efficiency simulation for key process parameters in biological methanogenesis. AIMS Bioeng 1(1):53-71. https://doi.org/10.3934/bioeng.2014.1.53

24. Meylan FD, Moreau V, Erkman S (2016) Material constraints related to storage of future European renewable electricity surpluses with $\mathrm{CO} 2$ methanation. Energy Policy 94:366-376. https://doi.org/10.1016/j.enpol. 2016.04.012

25. da Costa Gomez C (2017) Perspektiven des EEG 2017 für die Biogasbranche. GGG Fachseminar - Gärprodukte im Wandel der Zeit. www.gaerprodukte. de/downloads/01_da_Costa_Gomez.pdf. Accessed 27 Jan 2019

26. Deutsche Energie-Agentur GmbH (2018) Strategieplattform Power-to-Gas: Pilotprojekte. http://www.powertogas.info/power-to-gas/pilotprojekte-imueberblick/?no_cache=1\&tx_projektkarte_pi1\%5Baction\%5D=list\&tx projektkarte_pi1\%5Bcontroller\%5D=Projekte\&cHash=a1e608db0762ff23665 a8e46dcc9ade8. Accessed 31 Jan 2019

27. Bontempo G, Maciejczyk M, Wagner L et al. (2016) Biogas: Safety first!: guidelines for the safe use of biogas technology. https://www.biogas-safety. com/. Accessed 27 Mar 2018

28. Fendler R (2015) Existierende und geplante Anforderungen an die Sicherheit. https://energie-fr-de.eu/de/veranstaltungen/leser/konferenzueber-die-sicherheit-von-biogasanlagen-in-deutschland-und-frankreich.html. Accessed 27 Jan 2019

29. Casson Moreno V, Papasidero S, Scarponi GE et al (2016) Analysis of accidents in biogas production and upgrading. Renew Energy 96:11271134. https://doi.org/10.1016/j.renene.2015.10.017

30. Wagner $L$ (2015) Aktuelle sicherheitsrelevante Entwicklungen für Biogasanlagen. Fachverband Biogas e.V. (FVB). http://www.wetter.rlp.de/ Internet/global/themen.nsf/0/60080dec25c60c9ec1257f490038a011/\$FILE/ Sicherheitstour_Wagner.pdf. Accessed 16 Jan 2019

31. Cividino SRS, Malev O, Lacovig M et al (2015) BiogasAgriAtex, new methods of risk assessment explosion on biogas plants. Appl Math Sci 8:6599-6619. https://doi.org/10.12988/ams.2014.46449

32. Maciejczyk M (2015) Safety aspects of biogas plants. http://biovalor.gub.uy/ descarga/safety-aspects-biogas-plants/. Accessed 21 July 2019

33. Bundesministerium für Arbeit und Soziales, Bundesanstalt für Arbeitsschutz und Arbeitsmedizin (2006) Technische Regeln für Gefahrstoffe (TRGS). https://www.baua.de/DE/Angebote/Rechtstexte-und-Technische-Regeln/ Regelwerk/TRGS/TRGS.html. Accessed 14 Jan 2019

34. Deutsches Biomasseforschungszentrum (2011) Nachhaltige Biogaserzeugung in Deutschland - Bewertung der Wirkungen des EEG. http://www.fnr-server.de/ftp/pdf/berichte/22003410.pdf. Accessed 27 Jan 2019

35. Kampman B, Leguijt C, Scholten T et al. (2016) Optimal use of biogas from waste streams: an assessment of the potential of biogas from digestion in the EU beyond 2020. https://ec.europa.eu/energy/sites/ ener/files/documents/ce_delft_3g84_biogas_beyond_2020_final_report. pdf. Accessed 1 Aug 2019

36. Linhart $E$, Dhungel A-K (2013) Das Thema Vermaisung im öffentlichen Diskurs. Berichte über Landwirtschaft. Zeitschrift für Agrarpolitik und Landwirtschaft (2): Band 91. doi: https://doi.org/10.12767/BUEL.V91I2.22.G67

37. Herbes C, Pustišek A, McKenna R et al (2014) Überraschende Diskrepanz bei Biogas: lokal akzeptiert, global umstritten. Energiewirtschaftliche Tagesfragen 64:53-56

38. Csikos N, Schwanebeck M, Kuhwald M et al (2019) Density of biogas power plants as an indicator of bioenergy generated transformation of agricultural landscapes. Sustainability 11(9):2500. https://doi.org/10.3390/su11092500

39. Laggner B, Orthen N, Osterburg B et al (2014) Ist die zunehmende Biogasproduktion die alleinige Ursache für den Grünlandschwund in Deutschland? - eine Analyse von georeferenzierten Daten zur Landnutzung. Raumforsch Raumordn 72(3):195-209. https://doi.org/10. 1007/s13147-014-0278-7

40. Duttmann R, Hassenpflug W, Busch M et al. (eds) (2011) Winderosion in Schleswig-Holstein: Kenntnisse und Erfahrungen über Bodenverwehungen und Windschutz. Schriftenreihe LLUR SH Geologie und Boden, vol 15. Landesamt für Landwirtschaft Umwelt und ländliche Räume des Landes Schleswig-Holstein, Flintbek

41. Duttmann R, Schwanebeck M, Nolde M et al (2014) Predicting soil compaction risks related to field traffic during silage maize harvest. Soil Sci Soc Am J 78(2):408. https://doi.org/10.2136/sssaj2013.05.0198

42. Claus S, Taube F, Wienforth B et al (2014) Life-cycle assessment of biogas production under the environmental conditions of northern Germany: greenhouse gas balance. J Agric Sci 152(S1):172-181. https://doi.org/10. 1017/S0021859613000683

43. Kommission Landwirtschaft beim Umweltbundesamt (2013) Biogaserzeugung und-nutzung: Ökologische Leitplanken für die Zukunft Vorschläge der Kommission Landwirtschaft beim Umweltbundesamt (KLU). Agriculture Commission at the German Federal Environment, Dessau-Roßlau

44. Svoboda N, Taube F, Kluß C et al (2013) Crop production for biogas and water protection-a trade-off? Agric Ecosyst Environ 177:36-47. https://doi. org/10.1016/j.agee.2013.05.024

45. Brandt K, Glemnitz M (2014) Assessing the regional impacts of increased energy maize cultivation on farmland birds. Environ Monit Assess 186(2): 679-697. https://doi.org/10.1007/s10661-013-3407-9

46. Link P, Schleupner C (2007) Agricultural land use changes in Eiderstedt: historic developments and future plans Working Paper FNU-137. http:// epub.sub.uni-hamburg.de/epub/volltexte/2012/16273/pdf/Link_Schleupner_ Working_Paper_FNU_137.pdf.

47. Appel F, Ostermeyer-Wiethaup A, Balmann A (2016) Effects of the German Renewable Energy Act on structural change in agriculture: the case of biogas. Util Policy 41:172-182. https://doi.org/10.1016/j.jup.2016.02.013

48. Habermann H, Breustedt $G$ (2011) Einfluss der Biogaserzeugung auf landwirtschaftliche Pachtpreise in Deutschland: Einfluss der Biogaserzeugung auf landwirtschaftliche Pachtpreise in Deutschland. Ger J Agric Econ 60:85

49. Markard J, Wirth S, Truffer B (2016) Institutional dynamics and technology legitimacy - a framework and a case study on biogas technology. Res Policy 45(1):330-344. https://doi.org/10.1016/j.respol.2015.10.009

50. International Risk Governance Center (2017) Introduction to the IRGC risk governance framework: revised version. EPFL International Risk Governance Center, Lausanne https://irgc.epfl.ch/wp-content/uploads/2018/10/IRGC.-201 7.-An-introduction-to-the-IRGC-Risk-Governance-Framework.-Revised-version. pdf. Accessed 27 Jan 2019

51. Klinke A, Renn O (2012) Adaptive and integrative governance on risk and uncertainty. J Risk Res 15(3):273-292. https://doi.org/10.1080/ 13669877.2011 .636838

52. Sellke P, Renn O (2010) Risk, society and environmental policy: risk governance in a complex world. In: Gross M, Heinrichs H (eds) Environmental sociology: European perspectives \& interdisciplinary challenges. Springer-Verlag, Dordrecht, pp 295-321

53. Renn O, Klinke A (2015) Risk governance and resilience: new approaches to cope with uncertainty and ambiguity. In: Paleo UF (ed) Risk governance: the articulation of hazard, politics and ecology. Springer Netherlands, Dordrecht, pp 19-41

54. Crano WD, Brewer MB, Lac A (2015) Principles and methods of social research, 3rd edn. Routledge, New York, Hove

55. Bryman A (2012) Social research methods, 4th edn. Oxford Univ. Press, Oxford

56. Bernard HR (2011) Research methods in anthropology: qualitative and quantitative approaches, 5th edn. AltaMira, Lanham

57. Gerkensmeier B, Ratter BMW (2018) Governing coastal risks as a social process - facilitating integrative risk management by enhanced multistakeholder collaboration. Environ Sci Pol 80:144-151. https://doi.org/10. 1016/j.envsci.2017.11.011

58. Hitzler R, Honer A, Maeder C (1994) Expertenwissen: Die institutionalisierte Kompetenz zur Konstruktion von Wirklichkeit. Vieweg+Teubner Verlag, Wiesbaden

59. Meuser M, Nagel U (2009) The expert interview and changes in knowledge production. In: Bogner A, Littig B, Menz W (eds) Interviewing experts. Palgrave Macmillan, London

60. Bogner A, Menz W (2002) Das theoriegenerierende Experteninterview: Erkenntnisinteresse, Wissensformen, Interaktion. In: Bogner A, Littig B, Menz W (eds) Das Experteninterview: Theorie, Methode, Anwendung. VS Verlag für Sozialwissenschaften, Wiesbaden, pp 33-70

61. Aven T, Renn O (2009) On risk defined as an event where the outcome is uncertain. J Risk Res 12(1):1-11. https://doi.org/10.1080/13669870802488883

62. Aven T, Renn O (2010) Risk management and governance: concepts, guidelines and applications. Risk, governance and society, vol 16. Springer, Berlin

63. Renn O, Benighaus C (2013) Perception of technological risk: insights from research and lessons for risk communication and management. J Risk Res 16(3-4):293-313. https://doi.org/10.1080/13669877.2012. 729522

64. Kuckartz U (2014) Qualitative text analysis: a guide to methods, practice and using software. SAGE Publications Ltd, London 
65. Schulz J (2012) Analysing your interviews: research methods series. University of Southampton https://youtu.be/59GsjhPolPs. Accessed 15 Mar 2017

66. Saldaña J (2016) The coding manual for qualitative researchers, 3rd edn. Sage, Los Angeles

67. Döring N, Bortz J (2016) Forschungsmethoden und Evaluation in den Sozialund Humanwissenschaften. Springer Berlin Heidelberg, Berlin, Heidelberg

68. Rohrmann B, Renn O (2010) Risk perception research. In: Renn O, Rohrmann $B$ (eds) Cross-cultural risk perception: a survey of empirical studies. Kluwer Academic publishers, Dordrecht, pp 11-53

69. Keck C, Reiners W, Wein E (2017) Gülle in Engstingen ausgelaufen: Biogasanlage offenbar noch nicht genehmigt. https://www. stuttgarter-zeitung.de/inhalt.gaersubstrat-ausgelaufen-biogas-unfallanlage-nicht-freigegeben.ea418edb-f261-49b4-8d51-c1de8e2c58f8. html. Accessed 27 Mar 2017

70. Trávníček P, Kotek L, Junga P et al (2018) Quantitative analyses of biogas plant accidents in Europe. Renew Energy 122:89-97. https://doi.org/10.1016/ j.renene.2018.01.077

71. DPA (2016) Landwirt stirbt bei Unfall in einer Biogasanlage, Kißlegg https://www.suedkurier.de/ueberregional/baden-wuerttemberg/Kisslegg Landwirt-stirbt-bei-Unfall-in-einer-Biogasanlage;art417930,9042558. Accessed 22 June 2018

72. Kräft G (2015) Biogasanlage Bilshausen havariert: Tausende Liter Gärsubstrat ausgelaufen: Gerissene Leitung. http://www.goettinger-tageblatt.de/DieRegion/Duderstadt/Biogasanlage-Bilshausen-havariert-Tausende-LiterGaersubstrat-ausgelaufen. Accessed 26 Mar 2018

73. Wildavsky A, Dake K (1990) Theories of risk perception: who fears what and why? Daedalus 119(4):41-60

74. Douglas M (1992) Risk and blame: essays in cultural theory. Routledge, London, New York

75. McEvoy J, Gilbertz SJ, Anderson MB et al (2017) Cultural theory of risk as a heuristic for understanding perceptions of oil and gas development in Eastern Montana, USA. Extr Ind Soc 4(4):852-859. https://doi.org/10.1016/j.exis.2017.10.004

76. Rae A, Alexander R (2017) Forecasts or fortune-telling: when are expert judgements of safety risk valid? Saf Sci 99(Part B):156-165. https://doi.org/ 10.1016/j.ssci.2017.02.018

77. Xue W, Hine DW, Loi NM et al (2014) Cultural worldviews and environmental risk perceptions: a meta-analysis. J Environ Psychol 40(Supplement C):249-258. https://doi.org/10.1016/j.jenvp.2014.07.002

78. Rayner S (1992) Cultural theory and risk analysis. In: Krimsky S, Golding D (eds) Social theories of risk. Praeger Publishers, USA, pp 83-95

79. Oltedal S, Moen BE, Klempe $\mathrm{H}$ et al (2004) Explaining risk perception: an evaluation of cultural theory. Norwegian University of Science and Technology, Department of Psychology, Trondheim http://www.svt.ntnu.no/ psy/Torbjorn.Rundmo/Cultural_theory.pdf. Accessed 27 Jan 2019

80. Jaeger CC, Rosa EA, Renn O et al (2001) Risk, uncertainty, and rational action. Risk, society, and policy series. Earthscan, London

81. Jenssen $T$ (2010) The good, the bad, and the ugly: acceptance and opposition as keys to bioenergy technologies. J Urban Technol 17(2):99_ 115. https://doi.org/10.1080/10630732.2010.515086

82. Davy B (2008) Plan it without a condom! Plan Theory 7(3):301-317. https:// doi.org/10.1177/1473095208096885

83. Harmgart H, Huck S, Müller W (2006) Tannhäuser's dilemma: a study in rational choice hermeneutics. https://www.researchgate.net/publication/23 7445473_Tannhauser's_Dilemma_A_Study_in_Rational_Choice_ Hermeneutics. Accessed 25 Jan 2019

84. Al Seadi T, Stupak I, Smith CT Governance of environmental sustainability of manure-based centralised biogas production in Denmark: Murphy, J.D. (Ed.) IEA Bioenergy Task 37, 2018: 7. https://www.ieabioenergy.com/publications/ governance-of-environmental-sustainability-of-manure-based-centralisedbiogas-production-in-denmark/. Accessed 27 Jan 2019

85. van Dijk H, Fischer ARH, Marvin HJP et al (2015) Determinants of stakeholders' attitudes towards a new technology: nanotechnology applications for food, water, energy and medicine. J Risk Res 20(2):277-298. https://doi.org/10.1080/13669877.2015.1057198

86. Sjöberg L (1999) Risk perception by the public and by experts: a dilemma in risk management. Hum Ecol Rev 6(2). https://pdfs.semanticscholar.org/44 a4/1e1f21e1bb06bc161fae4ebc4c0b9578117a.pdf?_ga=2.22869432.2052693 700.1568360560-2103570968.1568360560.

87. Sala R, Oltra C (2011) Experts' attitudes towards CCS technologies in Spain. Int J Greenhouse Gas Control 5(5):1339-1345. https://doi.org/10. 1016/j.ijggc.2011.07.007
88. Sjöberg $L$ (2002) The allegedly simple structure of experts' risk perception: an urban legend in risk research. Sci Technol Hum Values 27(4):443-459. https://doi.org/10.1177/016224302236176

89. Andersson P, Edman J, Ekman M (2005) Predicting the World Cup 2002 in soccer: performance and confidence of experts and non-experts. Int J Forecast 21:565-576

90. Waylen AE, Horswill MS, Alexander JL et al (2004) Do expert drivers have a reduced illusion of superiority? Transp Res F 7:323-331

91. Weinstein ND (1980) Unrealistic optimism about future life events. J Pers Soc Psychol 39:806-820

92. Bostrom A (1997) Risk perception: "experts" vs. "lay people". Duke Environ Law Policy Forum 8:101-113

93. Duckett D, Wynne B, Christley RM et al (2015) Can policy be risk-based?: the cultural theory of risk and the case of livestock disease containment. Sociol Rural 55(4):379-399. https://doi.org/10.1111/soru.12064

94. Krewski D, Turner MC, Lemyre L et al (2012) Expert vs. public perception of population health risks in Canada. J Risk Res 15(6):601-625. https://doi.org/ 10.1080/13669877.2011.649297

95. Fromm J (2005) Risk denial and neglect: studies in risk perception. Dissertation, Stockholm School of Economics. ISBN nr 91-7258-689-3. https://ex.hhs.se/dissertations/377299-FULLTEXT01.pdf.

96. Weinstein ND, Klein WM (2002) Resistance of personal risk perceptions to debiasing interventions. In: Gilovich T, Griffin D, Kahneman D (eds) Heuristics and biases: the psychology of intuitive judgment. Cambridge University Press, New York

97. van der Pligt J (1994) Risk appraisal and health behaviour. In: Rutter DR, Quine L (eds) Social psychology and health: European perspectives. Avebury, Aldershot, pp 131-151

98. Persson T, Murphy J, Jannasch A et al (2014) A perspective on the potential role of biogas in smart energy grids. In: Baxter D (ed) . IEA Bioenergy http:// task37.jeabioenergy.com/files/daten-redaktion/download/Technical\%2 OBrochures/Smart_Grids_Final web.pdf. Accessed 29 Jan 2019

99. DPA (2017) Landwirt stirbt in betriebseigener Biogasanlage. http:// www.nordbayern.de/region/wei\%C3\%9Fenburg/landwirt-stirbt-inbetriebseigener-biogasanlage-1.5926731?rssPage=UmVnaW9u. Accessed 22 June 2018

100. Aul R (2018) Grundwasser bei Rockenbach wohl nicht gefährdet. https://www.br.de/nachricht/mittelfranken/inhalt/guelle-ausgelaufengrundwasser-bei-rockenbach-wohl-nicht-gefaehrdet-100.html. Accessed 31 Jan 2019

101. Maaz N (2015) Unfall in Treischfelder Biogasanlage: Tote Fische in der Taft. https://www.hersfelder-zeitung.de/lokales/hohenroda-eiterfeld/unfalltreischfelder-biogasanlage-tote-fische-taft-5578347.html. Accessed 31 Jan 2019

102. Keck C (2018) Betreiberfirma verspricht Entschädigung. https://www. stuttgarter-nachrichten.de/inhalt.nach-unglueck-in-engstinger-biogasanlagebetreiberfirma-verspricht-entschaedigung.f2d70a78-cb55-4fa5-8c4c-acb3382 ca2bchtml. Accessed 22 June 2018

103. Behn E (2018) Ausgelaufene Gülle bedroht Gewässer. http://www.kn-online. de/Lokales/Segeberg/Guelle-Unfall-an-Biogasanlage-Brokenlande-bedrohtGewaesser. Accessed 22 June 2018

104. Grunow R (2017) Schwerer Unfall an Biogasanlage. http://www.maz-online. de/Lokales/Ostprignitz-Ruppin/Schwerer-Unfall-an-Biogasanlage. Accessed 31 Jan 2019

105. Neumann A (2016) Zwischenfall an Biogasanlage Thierbach während des Probebetriebes. http://www.lvz.de/Region/Borna/Zwischenfall-anBiogasanlage-Thierbach-waehrend-des-Probebetriebes. Accessed 31 Jan 2019

106. Renn O, Rohrmann B (2000) Cross-cultural risk perception research: state and challenges. In: Renn O, Rohrmann B (eds) Cross-cultural risk perception: a survey of empirical studies. Kluwer, Dordrecht, pp 211-233

107. Tversky A, Kahneman D (1974) Judgment under uncertainty: heuristics and biases. Science 185(4157):1124-1131

108. Fromm J (2006) Experts' views on societal risk attention. J Risk Res 9(3):243264. https://doi.org/10.1080/13669870600603287

109. Harris J, Hassall M, Muriuki G et al (2018) The demographics of nuclear power: comparing nuclear experts', scientists' and non-science professionals' views of risks, benefits and values. Energy Res Soc Sci 46:29-39. https://doi. org/10.1016/j.erss.2018.05.035

110. Sjöberg L, Peterson M, Fromm J et al (2005) Neglected and overemphasized risks: the opinions of risk professionals. J Risk Res 8(7-8):599-616. https://doi. org/10.1080/13669870500062576 
111. Boholm Å, Prutzer M (2017) Experts' understandings of drinking water risk management in a climate change scenario. Clim Risk Manag 16:133-144. https://doi.org/10.1016/j.crm.2017.01.003

112. Lin S-W, Bier VM (2008) A study of expert overconfidence. Reliab Eng Syst Saf 93(5):711-721. https://doi.org/10.1016/j.ress.2007.03.014

113. Hall J, Bachor V, Matos S (2014) The impact of stakeholder heterogeneity on risk perceptions in technological innovation. Technovation 34(8):410-419. https://doi.org/10.1016/j.technovation.2013.12.002

114. Köhler AR, Som C (2014) Risk preventative innovation strategies for emerging technologies the cases of nano-textiles and smart textiles. Technovation 34(8): 420-430. https://doi.org/10.1016/j.technovation.2013.07.002

115. International Risk Governance Council (2018) The pros and cons of stakeholder involvement. https://www.irgc.org/stakeholder/resourceguide/5-the-pros-and-cons-of-stakeholder-involvement. Accessed 20 Apr 18

116. Köppel W, Gubkina N, McKenna R et al. (2017) PtG-Konzepte mit hoher gesellschaftlicher Akzeptanz für eine effiziente und flexible Speicher- und Energieinfrastruktur zur Integration Erneuerbarer Energien in BadenWürttemberg - Förderkennzeichen: BWE 13021 -13026: Forschungsbericht BWPLUS - Im Auftrag des Landes Baden-Württemberg. http:// fachdokumente.lubw.baden-wuerttemberg.de/servlet/is/126613/bwe13 021-26.pdf?command=downloadContent\&filename=bwe13021-26.pdf\&FIS= 203. Accessed 14 Jan 2019

117. Renn $\mathrm{O}$ (2015) Stakeholder and public involvement in risk governance. Int J Disaster Risk Sci 6(1):8-20. https://doi.org/10.1007/s13753-015-0037-6

118. Freeman RE (1984) Strategic management. Cambridge University Press, Cambridge

119. Derakhshan R, Turner R, Mancini M (2019) Project governance and stakeholders: a literature review. Int J Proj Manag 37(1):98-116. https://doi. org/10.1016/j.jproman.2018.10.007

120. Kasperson RE, Renn O, Slovic P et al (1988) The social amplification of risk: a conceptual framework. Risk Anal 8(2):177-187. https://doi.org/10.1111/j. 1539-6924.1988.tb01168.x

121. Kasperson RE, Jhaveri N, Kasperson JX (2001) Stigma and the social amplification of risk: towards a framework of analysis. In: Slovic P, Flynn J, Kunreuther $\mathrm{H}$ (eds) Risk, media and stigma: understanding public challenges to modern science and technology. Taylor and Francis, Hoboken, pp 9-27

122. Mase AS, Cho H, Prokopy LS (2015) Enhancing the social amplification of risk framework (SARF) by exploring trust, the availability heuristic, and agricultural advisors' belief in climate change. J Environ Psychol 41:166-176. https://doi.org/10.1016/j.jenvp.2014.12.004

\section{Publisher's Note}

Springer Nature remains neutral with regard to jurisdictional claims in published maps and institutional affiliations.

Ready to submit your research? Choose BMC and benefit from:

- fast, convenient online submission

- thorough peer review by experienced researchers in your field

- rapid publication on acceptance

- support for research data, including large and complex data types

- gold Open Access which fosters wider collaboration and increased citations

- maximum visibility for your research: over $100 \mathrm{M}$ website views per year

At $\mathrm{BMC}$, research is always in progress.

Learn more biomedcentral.com/submissions 